\title{
Pemilihan Gubernur DKI Jakarta 2017 dalam Meme: Sebuah Analisa Isi Terhadap Meme-meme di Dunia Maya
}

\author{
Nuning Kurniasih \\ Nuning Kurniasih, Program Studi Ilmu Perpustakaan, Fakultas Ilmu Komunikasi, Universitas Padjadjaran \\ e-mail: nuning.kurniasih@unpad.ac.id ; nuningkurniasih@yahoo.com \\ Prosiding Seminar Nasional dan Kebudayaan, Fakultas Ilmu Sosial dan Politik (FISIP) Universitas \\ Padjadjaran, 24-25 Oktober 2016. Penerbit: Unpad Press, Bandung. Halaman: 279-284
}

\begin{abstract}
This study aims to analyze the images, message content, the goals, and netizen's responds towards the memes in the internet (internet memes). The method used is qualitative method with content analysis approach to 40 internet memes related to the election of Governor of Jakarta in 2017. The results indicate (1) the images shown in the memes are the pictures of the candidates, the political figures of the supporting parties and actresses; activities, program or DKI Jakarta's condition; comics and the pictures of the people, (2) the messages in the memes including the candidates' profile, the candidates' profile comparison, the candidates' commitments or statements, the supporting parties' commitments or statements, a campaign to participate in the election as well as innuendo towards the candidates, (3) these memes by the netizen made to show public participations, entertain, a creativity, an innuendo/satire, social critic, delivering information more than merely texts, representing the candidates' achieved performances or one candidate's superiorities among the others also a supportive act towards certain a candidate, (4) the netizen's responds towards the memes are varied: netizens tend to post or share memes that can strengthen its support to a gubernatorial candidate, netizens feel comforted by their entertaining or humorous memes, offered prayers and positive statements when agreed with a message in a meme, respond to sarcasm when finding meme satire and social criticism. This study might contribute in choosing and determining alternative media to deliver campaign messages during the governor election.
\end{abstract}

Keywords - Governor Election, Memes, Information Media, Creativity, Social Media

Abstrak -Penelitian ini bertujuan untuk menganalisa gambar, isi pesan, tujuan dan tanggapan netizen terhadap meme-meme yang beredar di dunia maya (internet memes). Metode yang dipergunakan adalah metode kualitatif dengan pendekatan analisa isi terhadap 40 meme yang terkait Pemilihan Gubernur Jakarta 2017. Hasil penelitian menunjukkan bahwa (1) gambar-gambar yang dimunculkan dalam meme berupa tokoh yaitu calon gubernur, tokoh-tokoh di balik partai pengusung dan artis ; kegiatan, program atau kondisi wilayah DKI Jakarta ; komik dan foto masyarakat lainnya, (2) pesan yang disampaikan dalam meme mencakup profil calon gubernur pilihan, perbandingan diantara para calon gubernur, janji-janji atau pernyataan dari para calon gubernur, janji-janji atau pernyataan dari tokoh partai pengusung, pesan untuk berpartisipasi di dalam pemilihan gubernur dan sindiran terhadap para tokoh, (3) tujuan netizen menampilakan meme adalah sebagai wujud partisipasi masyarakat dalam proses pemilihan gubernur, untuk hiburan, menunjukkan kreativitas, sindiran/satire, kritik sosial, menyampaikan informasi lebih dari sekedar teks dan menunjukan kapasitas para calon serta mengajak netizen lain mendukung calon gubernur tertentu, (4) tanggapan netizen terhadap meme yang berkembang adalah bervariasi, cenderung untuk memuat atau membagikan memememe yang dapat memperkuat dukungannya terhadap calon gubernur tertentu, netizen merasa terhibur dengan adanya meme-meme yang menghibur atau bersifat humor, memberikan doa dan pernyataan membangun ketika setuju dengan pesan dalam sebuah meme, memberikan tanggapan sarkasme ketika menemukan meme satire dan kritik sosial. Hasil penelitian ini diharapkan dapat memberikan kontribusi didalam pemilihan media alternatif untuk penyampaian pesan dalam kampanye pemilihan kepala daerah.

Kata Kunci - Pemilihan Gubernur, Meme, Media Informasi, Kreativitas, Media Sosial

\section{PENDAhUluAN}

Pemilihan Gubernur (Pilgub) DKI Jakarta akan dilaksanakan pada tahun 2017. Namun demikian, sejak awal tahun 2016, antusiasme masyarakat menyambut Pilgub tersebut sudah terasa. Di dunia maya, terutama di media sosial, Pemilihan Gubernur DKI Jakarta berhasil menarik perhatian, tidak hanya bagi warga DKI Jakarta, tetapi juga bagi masyarakat Indonesia secara umum. Perhatian dari masyarakat dunia maya (netizen) ditandai dengan banyaknya pesan, baik berupa status ataupun tanggapan terhadap para calon gubernur dan proses pemilihannya. Sebagaimana pemilihan presiden ataupun pemilihan kepala daerah lainnya, Pilgub DKI Jakarta juga memunculkan kreativitas netizen dalam menyampaikan pesan. Salah satu kreativitas adalah dengan munculnya memememe terkait Pilkada DKI Jakarta.

Meme berasal dari kata mimeme yang digunakan untuk menjelaskan evolusi kebudayaan. Istilah ini mulai diperkenalkan Richard Dawkins pada tahun 1976. Menurut Brodie (2005), meme tanpa sadar menjangkiti manusia dan menyebar ke otak seperti virus.

Dalam politik, pesan kritis pada meme di jejaring sosial "Path" digambarkan melalui humor satir dengan menggunakan tanda visual dan tanda verbal yang dianalisis melalui ikon, indeks dan simbol (Pusanti \& Haryanto, 2015). Di Instagram, ada lima motif yang melatarbelakangi pengguna Instagram memasang meme, yaitu motif ingin tahu, motif menghibur, motif cinta, motif ekspresi, dan motif harga diri. Dengan memememe ini, mereka merasa diperhatikan dan memberikan informasi kepada followers, serta mendapatkan pengalaman baru (Nugraha, Sudrajat, \& Putri, 2015).

Dalam proses Pilgub DKI Jakarta tahun 2017, sampai dengan 
bulan Oktober 2016 ini ada beberapa momen menarik yaitu diawali dengan munculnya tokoh-tokoh yang berminat mencalonkan diri sebagai Gubernur DKI Jakarta, antara lain Basuki Tjahja Purnama (Ahok), Yusril Izha Mahendra, Adiyaksa Dault, Sandiaga Uno, Rizal Ramli dan Ahmad Dhani. Kemudian pengumuman calon gubernur oleh partai pengusung. Pada momen ini masyarakat dikejutkan oleh dua calon yang muncul, yaitu Agus Harimurti Yudhoyono dan Anies Baswedan. Dalam perjalanan selanjutnya, masyarakat juga ramai menanggapi pernyataan Ahok terkait Surat Al Maidah Ayat 51 serta pengangkatan Ignasius Jonan sebagai Menteri Energi dan Sumber Daya Mineral (ESDM) yang dikaitkan dengan Mantan Menteri Pendidikan dan Kebudayaan yang kini menjadi salah satu calon gubernur DKI Jakarta, yaitu Anies Baswedan. Momen-momen ini mendapat perhatian luar biasa dari masyarakat dunia maya. Banyak meme yang dimunculkan netizen di internet terkait momen-momen tersebut.

Penelitian ini bertujuan untuk menganalisa gambar dan isi pesan yang terdapat pada meme-meme Pilgub DKI Jakarta 2017, tujuan dibuatnya meme-meme Pilgub DKI Jakarta 2017, serta tanggapan netizen terhadap meme-meme Pilgub DKI Jakarta yang beredar di internet tersebut, terutama terkait empat momen sebagaimana telah diuraikan di atas. Hasil penelitian ini diharapkan dapat memberikan kontribusi di dalam pemilihan media alternatif untuk penyampaian pesan dalam kampanye pemilihan kepala daerah atau kepala pemerintahan.

\section{METODE}

Metode yang digunakan dalam penelitian ini adalah metode penelitian kualitatif dengan pendekatan analisa isi. Analisa ini mencakup teknik untuk menganalisa teks secara sistematis (Mayring 2000). Studi kualitatif analisis isi dimulai dengan mengidentifikasi dan mengkuantifikasi kata-kata dalam teks dengan tujuan untuk memahami penggunaan kata secara kontekstual. Pendekatan analisa isi secara kualitatif mencakup analisa isi yang tersembunyi yang merujuk pada interpretasi (Hsieh and Shannon 2005).

Dalam penelitian ini pengumpulan data dilakukan dengan menganalisa gambar dan isi pesan pada meme-meme yang beredar di internet. Meme-meme itu sendiri biasanya menyebar secara viral sehingga kemungkinan besar, meme yang beredar di semua platform internet, termasuk di media sosial adalah meme yang sama. Dari banyaknya meme yang beredar, peneliti membatasi meme yang terkait empat hal, yaitu (1) kehadiran para tokoh yang meramaikan bursa bakal calon gubernur DKI Jakarta 2017, (2) pengumuman calon gubernur DKI Jakarta oleh partai pengusung, (3) tanggapan terhadap pernyataan Ahok yang mengutip Al Quran Surat Al Maidah ayat 51 dan (4) momen pengumuman Ignasius Jonan sebagai menteri ESDM yang dikaitkan dengan dengan Anies Baswedan. Dengan pembatasan tersebut, peneliti mengambil contoh 40 meme yang merupakan hasil penelusuran melalui search engine google dengan kata kunci "Meme Pilgub DKI Jakarta 2017”..

Selanjutnya, peneliti melakukan observasi lebih lanjut terhadap blog pribadi atau akun media sosial yang memuat dan menyebarkan meme-meme tersebut untuk mengetahui tujuan dibuatnya meme Pilgub DKI Jakarta dan tanggapan netizen terhadap meme-meme tersebut. Untuk lebih meyakinkan interpretasi peneliti terhadap hasil analisa isi, peneliti juga melakukan wawancara (interaksi langsung) dengan beberapa netizen.

Pengolahan data dilakukan melalui koding sehingga mengasilkan kata kunci, dan selanjutnya diinterpretasi.

\section{HASIL DAN PEMBAHASAN}

\subsection{Gambar-gambar dan Isi Pesan pada Meme Pilgub DKI Jakarta 2017}

Pada awal bursa bakal calon Gubernur DKI Jakarta Tahun 2017, netizen mengangkat tiga tokoh yang dianggap layak memimpin Jakarta. Ketiga tokoh tersebut adalah Ahok, Ridwan Kamil (Walikota Bandung) dan Tri Rismarini (Walikota Surabaya). Meme-meme yang berkembang di internet berisi gambar ketiga tokoh tersebut dengan membandingkan prestasi dan kapasitas masing-masing dalam memimpin daerahnya. Meme-meme tersebut antara lain sebagai berikut:

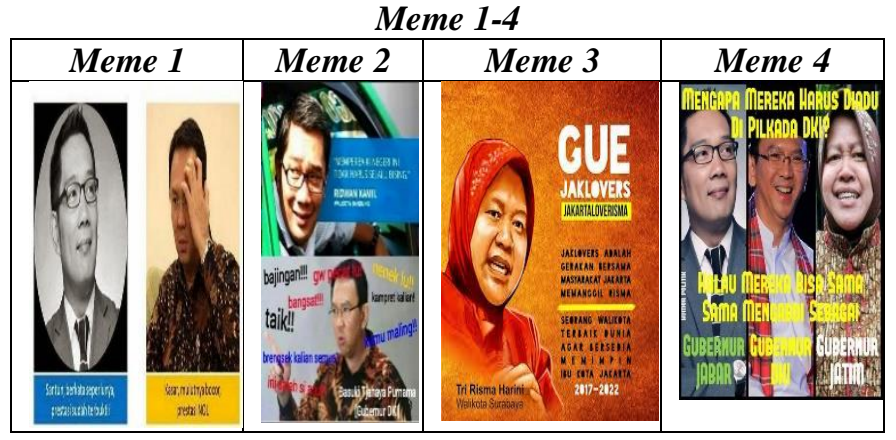

Keterangan: Meme dari Berbagai Sumber di Internet

Pada meme 1 dan 2, netizen membandingkan sosok Ahok dan Ridwan Kamil, dimana Ridwan Kamil dinilai sebagai pribadi yang lebih santun tutur katanya daripada Ahok. Pada meme 3, pembuat meme mengatasnamakan Jaklovers yang meminta Risma sebagai wali kota terbaik dunia agar mau memimpin Jakarta. Pada meme 1 dan 2, sudah jelas maksud dari pembuat meme adalah mendukung Ridwan Kamil untuk maju dalam pemilihan gubernur DKI Jakarta, sedangkan pada meme 3, mendukung Risma untuk menjadi gubernur DKI Jakarta. Pada meme 4, netizen berpendapat bahwa ketiga tokoh tersebut, baik Ahok, Ridwan Kamil maupun Risma bisa menjadi pemimpin di wilayahnya masing-masing sehingga tidak perlu bersaing untuk DKI I. Meme 4 menunjukkan dukungannya kepada Ahok untuk menjadi gubernur DKI Jakarta. Isi pesan yang terdapat pada keempat meme ini dapat ditangkap langsung oleh siapapun yang melihatnya.

Ketika Ridwan Kamil mengumumkan tidak akan maju ke Pilgub DKI Jakarta, kemudian muncul meme berisi gambar Ridwan Kamil dan istrinya Atalita Kamil dalam bentuk katun yang diunggah oleh seorang warga Surabaya dengan akun ahmad_syahirul_basyir dan diunggah ulang dalam Facebook Ridwan Kamil pada 1 Maret 2016 dengan judul "Behind the scene. Karena wanita selalu benar" (Lihat Lampiran Meme 5). Dalam meme tersebut diceritakan ketidaksetujuan istri Ridwan Kamil apabila Ridwan Kamil maju dalam pemilihan gubernur DKI Jakarta. Isi meme tersebut, tentu hanya sebuah guyonan untuk menghibur. 
Meme berisi gambar dan kartun juga muncul untuk menggambarkan para tokoh yang ingin mencalonkan diri atau yang mungkin dicalonkan menjadi Gubernur DKI Jakarta seperti Yusril Izha Mahendra, Adiyaksa Dault, Sandiaga Uno, Rizal Ramli dan Ahmad Dhani (lihat Lampiran Meme 6). Yusril Izha Mahendra dan Ahmad Dhani mendapatkan sebuah meme sindiran yang berkenaan dengan kegagalan rumah tangga keduanya. Dalam meme tersebut ditampilkan gambar keduanya dengan teks "Yus** dan Dha** mimpin warga Jakarta? Mimpin rumah tangga sendiri saja gagal"(lihat Lampiran Meme 7). Meme ini sepertinya dibuat oleh orang yang tidak mendukung keduanya maju menuju DKI 1.

Meme lainnya berbentuk modifikasi gambar diri para bakal calon gubernur menyerupai artis atau pemeran film (lihat Lampiran Meme 8), tokoh senior dari partai pendukung bakal calon gubernur, serta kegiatan atau kondisi wilayah DKI Jakarta.

Berkaitan dengan pengumpulan dukungan untuk Ahok maju menjadi calon independen. Banyak meme yang berisi wajah masyarakat umum memegang kertas berisikan "Saya pilih Ahok karena ..." dan "Saya Gak Mungkin Pilih Ahok karena ...". Pesan yang disampaikan di dalam meme-meme ini lebih banyak sebagai hiburan, seperti "Saya gak mungkin pilih Ahok karena saya sudah punya pacar", "Saya gak mungkin pilih Ahok, soalnya kata Anang, jangan memilih aku" (lihat Lampiran Meme 9). Namun ada juga pesan dalam meme tersebut yang menuliskan tidak mungkin memilih calon tertentu karena perbedaan agama. Dalam hal ini pesan yang ingin disampaikan oleh pembuat meme sepertinya adalah sama seperti teks yang disampaikan.

Kekecewaan sebagian netizen karena Ahok tidak memilih jalur independen juga tak lepas dari kreativitas pembuat meme, dimana nama "Teman Ahok" diplesetkan menjadi "Teman Kapok" dalam sebuah meme bergambar kaos dengan teks "Shold Out. Teman Kapok. Takut Independen 2017. Balikin KTP Gua" (lihat Lampiran Meme 10). Selanjutnya muncul meme-meme Ahok dengan "seteru" politiknya seperti dengan Lulung Lunggana dan Habiburrahman yang sejak awal meragukan Ahok maju lewat jalur independen.

Pada saat diumumkan tiga calon gubernur oleh para partai pengusung, pencalonan Agus Harimuri Yudhoyono (AHY) berhasil mengambil perhatian netizen. Netizen dikejutkan oleh keputusan AHY mundur dari TNI untuk maju menuju DKI 1. Netizen-pun menduga bahwa keputusan AHY semata-mata untuk memenuhi keinginan kedua orang tuanya, yaitu Soesilo Bambang Yudhoyono(SBY) dan Ibu Ani Yudhoyono. Memememe yang muncul berupa kepatuhan AHY kepada orang tua (lihat Lampiran Meme 11), sindiran terhadap ungkapan yang pernah disampaikan oleh SBY saat menjabat sebagai Presiden bahwa tidak tepat apabila ada TNI yang bercita-cita ingin menjadi bupati, walikota, gubernur, pengusaha, dll (Handr, 2009) (lihat Lampiran Meme 12), meme lucu sekaligus sindiran dengan teks "Papa jahaaat" (lihat lampiran Meme 13) untuk menunjukkan keheranan netizen mengapa SBY tidak memilih puteranya yang sudah berkarir di poitik yaitu Edhi Baskoro Yudhoyono dan meme untuk membandingkan putera SBY dengan putera Presiden Jokowi, yaitu Gibran Rangkabuming yang memilih menjadi pengusaha daripada politikus (lihat Lampiran Meme 14) hingga membandingkannya dengan Norman Kamaru, seseorang yang memutuskan berhenti menjadi polisi untuk menjadi artis.

Namun demikian, banyak juga meme yang mendukung AHY dalam Pilgub DKI Jakarta. Dalam meme-meme yang beredar, AHY digambarkan sebagai sosok yang tampan, sehingga disandingkakan dengan bintang Korea (lihat Lampiran Meme 15), santun, nasionalis dan agamais (lihat Lampiran 16).

Sementara itu, Anies Baswedan yang diusung oleh partai yang bersebrangan dengan partai yang didukungnya pada Pemilihan Presiden 2014, memunculkan meme kilas balik Pemilihan Presiden (Pilpres) 2014 (lihat Lampiran Meme 17). Disini netizen ingin mengungkapkan bahwa mereka masih ingat momen Pilpres 2014 dan mempertanyakan konsistensi terhadap pernyataan sang calon gubernur.

Ditetapkannya tiga calon gubernur DKI juga memunculkan meme dengan gambar perbandingan hardware dari tiga merek yang saat ini banyak dipergunakan oleh masyarakat dan dapat menggambarkan kapasitas masing-masing calon (lihat Lampiran Meme 18). Ketika para calon gubernur dan wakil gubernur melakukan pemeriksaan kesehatan, mereka melakukan foto bersama, foto inipun kemudian dimodifikasi oleh netizen. Ada yang mengganti wajah salah satu calon wakil gubernur, Silviana Murni dengan wajah Jonru, Ratna Sarumpaet, hingga artis Tika Panggabean.

Pilgub DKI Jakarta juga dimeriahkan oleh artis pendukung, seperti Sopia Lacuba yang diangkat menjadi salah seorang juru bicara Tim Ahok, ramalan feng shui, serta bakal calon yang tidak jadi diusung dengan teks "Yang rame dan yang jadi" (lihat Lampiran Meme 19).

Selanjutnya muncul meme-meme yang menunjukkan program dari calon gubernur, seperti meme dari pendukung Anies Baswedan, menampilkan gambar sang calon gubernur, calon wakil gubernur dan para sesepuh pendukung pasangan calon dengan teks "Jakarta yang baik itu adalah maju kotanya, bahagia warganya. Ada adab di kota ini. Adab harus dikembalikan di kota ini' (lihat Lampiran Meme 20). Terkait kata "adab" yang ada dalam teks tersebut, beberapa komentator meme menduga bahwa kata itu ditujukan untuk salah satu calon gubernur.

Polemik pernyataan Ahok berkaitan dengan Surat Al Maidah Ayat 51, memunculkan meme antara lain yang menjadi viral dengan gambar Nusron Wahid terkait pernyataannya tentang tafsir Al-Quran (lihat Lampiran Meme 21) dan Yusuf Mansur, menanggapi pernyataan Nusron Wahid. Meme lainnya adalah gambar Ahok yang sedang diwawancara oleh wartawan dengan teks "Breaking News. Ahok batal nyalon". Tentu saja meme ini bukan dalam arti batal nyalon sesungguhnya, melainkan hanya sebagai upaya pendukung Ahok meredakan ketegangan politik dimana akibat dari polemik tersebut, ada beberapa pihak yang memintanya mundur. Masih dalam yang meme sama ada teks lanjutan yaitu "Ahok memilih untuk tidak memotong rambutnya di salon".

Terakhir, dilantiknya kembali Ignasius Jonan sebagai meteri di kabinet Jokowi, memunculkan kreatifitas netizen yang menghubungkannya dengan mantan menteri yang menjadi calon gubernur, Anies Baswedan. Dalam meme yang beredar, netizen berpendapat, seandainya Anies dapat sedikit sabar, mungkin akan diangkat lagi sebagai menteri sebagaimana Jonan (lihat Lampiran meme 23).

3.2. Tujuan Disebarkannya Meme Pilgub DKI Jakarta 2017 


\section{oleh Netizen}

Berdasarkan pemaparan pada bagian 3.1., dapat dilihat bahwa pesan yang disampaikan dalam meme politik dapat berupa sesuatu yang serius ataupun sebuah humor. Menurut Dr Sophie Lecheler, meme memiliki peran penting untuk masa depan kampanye, meme dapat digunakan sebagai taktik persuasif dalam kampanye dengan potensi pendekatan akar rumput. Meme juga menawarkan cara baru bagi partisipasi masyarakat dalam mengekspresikan opini politiknya (Shifman, 2013).

Setidaknya ada tiga motif mengapa seseorang membuat meme, yaitu sebagai ekspresi diri, aktualisasi diri dan ingin mendapat tanggapan dari orang lain (Shao, 1999). Meme memiliki implikasi terhadap dunia politik karena sifatnya yang mudah dibuat dan disebarkan. Meme menjadi media kritik politik yang efektif dengan cara yang kreatif. Meme politik dapat membuat politik lebih inklusif dan mudah diakses terutama bagi anak muda yang aktif dan antusias mengkonsumsi budaya pop (Plevriti, 2014).

Berdasarkan analisa terhadap meme-meme Pilgub DKI Jakarta 2017 dan hasil interaksi terhadap beberapa netizen, dapat disimpulkan bahwa tujuan netizen membuat atau menyebarkan meme Pilgub DKI Jakarta 2017 adalah (1) sebagai bentuk partisipasi masyarakat dalam proses politik di DKI Jakarta (lihat Lampiran Meme 24). Dalam foto bersama ketiga pasangan calon gubernur dan wakil gubernur DKI Jakarta tertulis "calonnya saja damai, warganya koq rebut". Dari meme ini terlihat, netizen ingin agar masyarakat berpartisipasi dalam Pilgub dengan cara yang damai, (2) untuk hiburan, hal ini ditunjukkan dengan banyaknya meme humor politik, (3) menunjukkan kreativitas, dengan memodifikasi foto atau gambar, (4) sindiran/satire, (5) kritik sosial, (6) menyampaikan informasi lebih dari sekedar teks, (7) menunjukan program atau hasil kinerja, (8) menunjukkan kapasitas dengan mengupas kelebihan dan kelemahan para calon dibandingkan calon lainnya, dan (9) mengajak netizen lain mendukung calon gubernur tertentu.

\subsection{Tanggapan Netizen terhadap Meme Pilgub DKI 2017}

Untuk mengetahui tanggapan netizen terhadap meme Pilgub DKI Jakarta 2017, peneliti melakukan observasi langsung terhadap tulisan yang dibuat oleh netizen melalui beberapa blog pribadi dan akun media sosial yang memuat meme-meme tersebut.

Dari hasil observasi tersebut diketahui bahwa netizen cenderung untuk memuat atau membagikan meme-meme yang dapat memperkuat dukungannya terhadap calon gubernur tertentu. Netizen memuat dan membagikan meme-meme yang berisi pesan positif terhadap calon yang didukungnya dan memuat atau membagikan pesan yang bernada negatif untuk calon yang tidak didukungnya. Beberapa netizen memuat meme sebagai pengantar untuk mendiskusikan calon tertentu.

Netizen merasa terhibur dengan adanya meme-meme yang menghibur atau bersifat humor. Netizen memberikan doa dan pernyataan membangun ketika setuju dengan pesan dalam sebuah meme. Netizen memberikan tanggapan sarkasme ketika menemukan meme satire dan kritik sosial. Tidak jarang netizen terlibat pertengaran secara online ketika mendapati meme dan tanggapan yang tidak sesuai dengan pendapat pribadinya. Pertengkaran yang dimulai dengan komentar-komentar di media sosial ini, pada beberapa kasus membuat pertemanan di media sosial terputus.

\section{SIMPULAN}

Meme politik memberikan implikasi dalam dunia politik. Masyarakat dapat berpartisipasi secara langsung dengan mengekspresikan opininya melalui meme politik. Meme politik dapat mengindikasikan dukungan dan penolakan kepada seorang calon. Apabila hal ini dikelola dengan baik akan menghasilkan strategi kampanye kreatif dan efektif, terutama untuk meraih publik yang aktif di dunia maya dan terbiasa dengan budaya pop.

\section{UCAPAN TERIMA KASIH}

Penulis mengucapkan terima kasih kepada rekan-rekan penulis di media sosial yang aktif memberikan tanggapan dan berdiskusi tentang meme politik Pemilihan Gubernur DKI Jakarta.

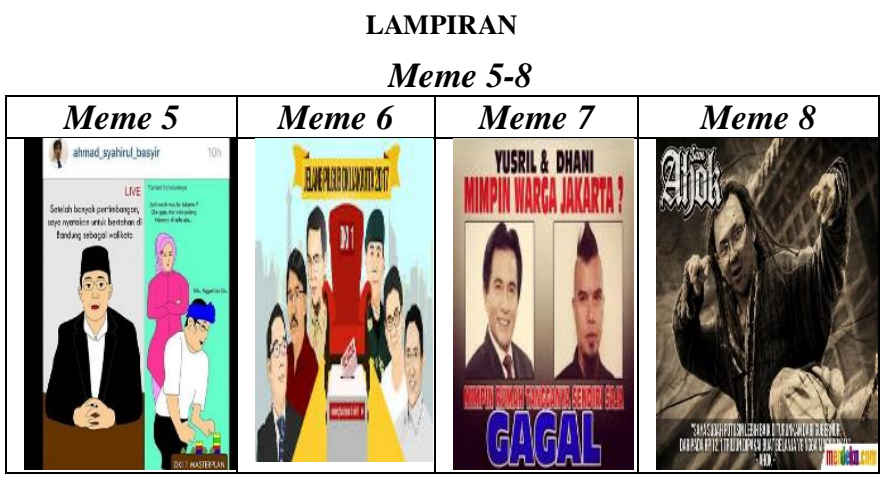

Keterangan: Meme dari Berbagai Sumber di Internet

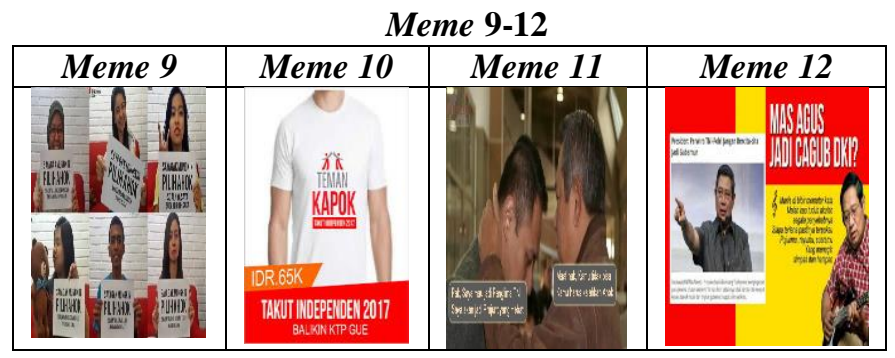

Keterangan: Meme dari Berbagai Sumber di Internet

Meme 13-16

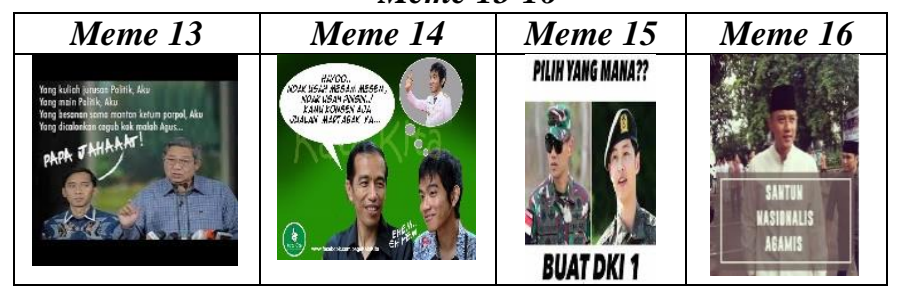

Keterangan: Meme dari Berbagai Sumber di Internet

Meme 17-20

\begin{tabular}{|l|l|l|l|} 
Meme 17 & Meme 18 & Meme 19 & Meme 20 \\
\hline
\end{tabular}




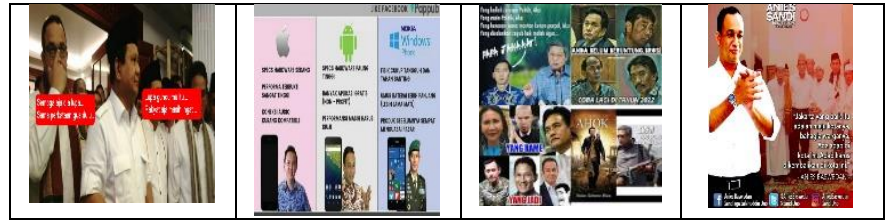

Keterangan: Meme dari Berbagai Sumber di Internet

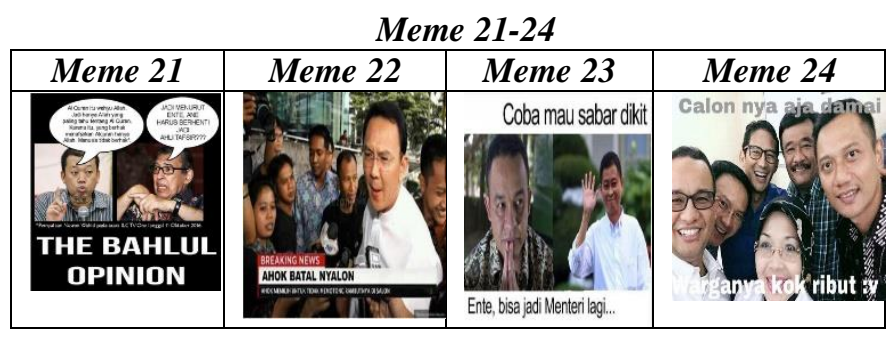

DAFTAR PUSTAKA

Blackmore, S. (2000). The POWER OF MEMES. IN S. AMERICAN, Brain To BraIN, MEMES Proliferate Through Society, BLINDLY EVOLVING AS THEY Go AND SHAP ING OUR Culture, Says The Author. (PP. 65-73). Us: ScIEnTIFIC AMERICAN, INC.

Brodie, R. (2011). Virus of the Mind: The New Theory of Meme Reissue Edition. USA: Hay House, Inc.

Chick, G. (1999). What's in a Meme? The Development of the Meme as a Unit of Culture. The Annual Meeting of the American Anthropological Association as part of the session, "Perceiving Culture: Unit Definition in Cultural Anthropology. US: American Anthropological Association .

Coscia, M. (2013). Competition and Success in the Meme Pool: a Case Study on Quickmeme.com. Seventh International AAAI Conference on Weblogs and Social Media (pp. 100109). US: Association for the Advancement of Artificial Intelligence (www.aaai.org).

Dawkins, R. (2006). The Selfish Gene. New York: Oxford University.

Handr. (2009, Desember 22). Presiden: Perwira TNI-Polri Jangan Bercita-cita Jadi Gubernur. Retrieved from AntaraNews:

http://www.antaranews.com/berita/166820/presidenperwira-tni-polri-jangan-bercita-cita-jadi-gubernur

Hsieh, H.-F., \& Shannon, S. E. (2005). Three Approaches to Qualitative Content Analysis. QUALITATIVE HEALTH RESEARCH, Vol. 15 No. 9, November, 1277-1288.

Mayring, P. (2000). Qualitative Content Analysis. Forum: Qualitative Social Research Vol.1 No.2, Art. 20 - June.

Nugraha, A., Sudrajat, R. H., \& Putri, B. P. (2015). Fenomena Meme di Media Sosial: Studi Etnografi Virtual Posting Meme pada Pengguna Media Sosial Instagram. Jurnal Sosioteknologi | Vol. 14, No 3, Desember, 273-245.

Plevriti, V. (2014). Satirical User-Generated Memes as an Effective Source of Political Criticism, Extending Debate and Enhancing Civic Engagement. UXS: The University of Warwick.

Pusanti, R. R., \& Haryanto. (2015). Representasi Kritik dalam Meme Politik (Studi Semiotika Meme Politik dalam Masa Pemilu 2014 pada Jejaring Sosial "Path" sebagai Media
Kritik di Era Siber). Jurnal Komunikasi Massa Program Studi Ilmu Komunikasi Fisip UNS, diakses melalui http://www.jurnalkommas.com/docs/JURNAL\%20ONLINE \%20REPRESENTASI\%20KRITIK\%20DALAM\%2OMEME \%20POLITIK_ROSA\%20REDIA-D1212069.pdf, 1-19.

Shao, G. (1999). Understanding the Appeal of User-Generated Media: a Uses and Gratification Perspective. Internet Research, Vol. 19 Iss: 1, 7-25.

Shifman, L. (2013). Memes in Digital Culture. Cambridge MA: The MIT Press.

Wijayanto, E. (2013). Memetics: Perspektif Evolusionis Membaca Kebudayaan. Depok: Kepik. 